\title{
Exploratory Study of Most Critical Business Communication Skills In Contemporary Corporate India
}

\author{
Deepak Verma ${ }^{1}$, Dr. Neerja Pande ${ }^{2}$ \\ ${ }^{1}$ Deepak Verma, Jaypee University, Noida. India, \\ Address: E-51, GF, Suncity, Sector 54, Gurgaon, India \\ deepakverma711@rediffmail.com \\ ${ }^{2}$ Dr. Neerja Pande, IIM Lucknow (Noida campus), India \\ neerja.pande63@gmail.com
}

\begin{abstract}
It has been observed that business communication plays a crucial role in the corporate world. The corporate executives need to demonstrate exceptional communication skills while performing their job roles, which helps them in reaching a sovereign position in this competitive business environment. The main intendment of this paper is to identify the essential attributes for business communication skills so that B-Schools can develop business communication curriculum and teaching methodology for their students which is most suited to contemporary corporate aspirations and anticipations.

For the identification of the most significant attributes on communication skills, we formed an expert panel by taking senior corporate executives from the industry. We selected those attributes which were categorized as critical or important by more than $60 \%$ of the panel members. As a result we were able to finalize a list of 41 Business Communication attributes that are valued by the corporate executives.

With these findings, B-Schools and their faculty members will have a clear view of the corporate expectation / requirements of business communication skills. Academicians can integrate these attributes and develop the course curriculum accordingly so that it can be benchmarked with corporate expectations. Students can also have a clear cut understanding on what communication skills are required in the corporate world so that they can prepare themselves with the desired attributes.
\end{abstract}

Indexing terms/Keywords: Business Communication Skills, Corporate India, Business Communication Curriculum

\section{Academic Discipline And Sub-Disciplines}

Management

\section{SUBJECT CLASSIFICATION}

Business Communication

\section{TYPE (METHOD/APPROACH)}

Survey/Interview: For the identification of the most significant attributes of eight core business communication skills, we formed an expert panel by taking senior corporate executives from the industry from diversified industry segments and work experience (ranging from 15 years to 35 years). We shared relevant attributes of business communication skills and requested them to identify and select the most important attributes keeping in mind corporate requirements and without getting biased by their own industry specifics so that we can get the business communication requirements from the general management point of view. Their opinions were taken through personal interactions and filling of a detailed questionnaire.

\section{Council for Innovative Research}

Peer Review Research Publishing System

Journal: International Journal of Management \& Information Technology

Vol. 7, No. 3

editor@cirworld.com

www.cirworld.com, member.cirworld.com 


\section{INTRODUCTION}

\section{Role of Business Schools}

In India we have a large number of B-Schools ranging from A+ category (Premier B-Schools) to $\mathrm{C}$ category (moderate B-Schools). Irrespective of their category, they have one common objective i.e. to train their students and make them ready for the corporate world. They try with the best of their capabilities and infrastructure to nurture the required skills of their students. Academicians design and develop the course curriculum keeping in mind the present day requirements and challenges of business world. Since we all know the importance of business communication in this challenging, competitive and global corporate world, it is imperative that due diligence is to be given while contemplating the curriculum / training methods for the subject.

\section{What is Business Communication?}

The word "Communicate" come from the Latin verb "Communicare" that means to impart, to participate, to share and to make common. By virtue of its Latin origin, it is also the source of the English word "Common". [1] Thus communication is defined as a two way process where the message sent by the sender should be interpreted in the same terms by the recipient. [2]

Lesikar et al affirm the significance of communication and linguistic capabilities and English language proficiency in the twenty-first century marketplace as reiterated recently by the Knowledge Commission. [3]

Communication needs to be effective in business as it is the essence of management. The basic functions of management - Planning, Organizing, Staffing, Directing and Controlling cannot be performed well without effective communication. Business communication involves constant flow of information and it is goal oriented. Thus we can say that "Business communication is the appropriate communication in the business environment with an objective to help in improving the profitability of the business".

In early times, business communication was limited to paper-work, telephone calls etc. But now with advent of technology, we have cell phones, video conferencing, emails and satellite communication to support business communication. Effective business communication helps in building goodwill of an organization.

\section{Importance of Business Communication}

Organizations these days are capacious and diversified as it involves enormous stakeholders, culture, manifold levels of hierarchy and legion countries to interact with. Greater the diversity, larger is the difficulty in managing the organization. Communication here plays a very significant role in the process of directing and controlling the people in the organization. A number of recent researches indicate that there is a strong link between communication competence of an individual and the success he or she achieves in the workplace.

Raina\&Pande state that there is no denying the fact that effective communication is at the root of virtually all success which mandates that even engineers, scientists and technocrats need to translate their work into understandable communications so that it can be applied outside their own level of expertise. [4] There should be effective communication between superiors and subordinates, across departments, across countries, and between organization and society at large. It is essential for success and growth of an organization that communication gaps should be totally removed or at least minimized.

Communication also plays a crucial role in altering individual's attitudes, i.e., a well-informed individual will have better attitude than a less-informed individual. Organizational magazines, journals, meetings and various other forms of oral and written communication help in moulding employee's attitudes.

\section{EXPECTATION OF CORPORATE}

An effective and efficient communication system requires managerial proficiency in delivering and receiving messages. A manager must discover various communications, analyze the reasons for their occurrence and take preventive steps to avoid those barriers. Thus, the primary responsibility of a manager is to develop and maintain an effective communication system in the organization. The characteristics of effective communication are as follows

1. Clarity of Purpose: The message to be delivered must be clear in the mind of sender.

2. Completeness: The message delivered should be supported by facts and observations and should be well planned and organized.

3. Conciseness: The message should be short and complete and should not include any superfluous or exorbitant details.

4. Feedback: The purpose of feedback is to understand whether the message sent by the sender is 
understood in same terms by the receiver or not.

5. Empathy: The speaker should step into the shoes of the listener and be sensitive to their needs and emotions. [5]

\section{METHODOLOGY}

With the help of extensive literature review and referring to various books on the subject, we tried to gain a deep insight into Business Communication and its dimensions. Business Communication can be said to incorporate the following eight critical skills:

1. Written Communication

2. Oral Communication

3. Listening Skills

4. Non Verbal Communication

5. Reading Skills

6. Technology

7. Ethical and Cultural Diversity

8. Personality

1. Written Communication: Written means of business communication includes - agenda, reports, manuals etc. Effective writing involves careful choice of words, their organization in correct order in sentences formation as well as cohesive composition of sentences. Written Communication helps in laying down apparent principles, policies and rules for running of an organization. [6]The major attributes for written communication are given below in Table I.

TABLE I Attributes for Written Communication

\begin{tabular}{|c|l|}
\hline 1 & Using correct English grammar \\
\hline 2 & Using correct sentence structure \\
\hline 3 & Completeness of communication \\
\hline 4 & Being precise /accurate in quoting figures \\
\hline 5 & Being veracious (honest) in writing / quoting facts \\
\hline 6 & Etiquettes for email writing \\
\hline 7 & Being affable and courteous while writing \\
\hline 8 & Taking into consideration reader's viewpoint \\
\hline 9 & Having lucidity (clarity) of thought and ideas \\
\hline 10 & Writing Memorandums \\
\hline 11 & Writing Reports \\
\hline 12 & Writing persuasive letters \\
\hline 13 & Writing good news/positive messages \\
\hline 14 & Writing bad news/negative messages \\
\hline 15 & Writing motivating, encouraging messages \\
\hline 16 & Documenting MOM (Minutes of Meeting) \\
\hline & \\
\hline
\end{tabular}

2. Oral Communication - Oral communication implies speeches, presentations, meetings, discussions, conferences, interviews etc. - be it face to face or remote. Oral communication is generally recommended where a direct interaction is required. It is important to have cogent oral communication skills as it is most frequently used in business dealings. [6]

The major attributes for oral communication are given below in Table II. 
TABLE II Attributes for Oral Communication

\begin{tabular}{|c|c|}
\hline 1 & Giving individual oral presentation \\
\hline 2 & Using correct pronunciation \\
\hline 3 & Using effective interpersonal skills \\
\hline 4 & Participating in group presentations \\
\hline 5 & Style of communication \\
\hline 6 & Participating in meetings \\
\hline 7 & Conducting meetings \\
\hline 8 & Refusing / saying 'NO' politely \\
\hline 9 & Closing conversation (those lead to nowhere) politely \\
\hline 10 & Good vocabulary \\
\hline 11 & Ability to package any object along with the subject \\
\hline 12 & Persuasive communication \\
\hline 13 & Clarity of thought \\
\hline 14 & Practical understanding of business \\
\hline 15 & Knowledge about the current affairs \\
\hline 16 & Fluency in speaking \\
\hline 17 & Using appropriate wordings \\
\hline 18 & Using precise/crisp sentences \\
\hline 19 & Using correct grammar while speaking \\
\hline 20 & Using humor while speaking \\
\hline 21 & Analytical and organized \\
\hline 22 & Telephone etiquettes \\
\hline 23 & Negotiation skills \\
\hline 24 & Resolving conflicts \\
\hline
\end{tabular}

3. Listening Skills-Listening is not same as hearing, it involves the process of selecting, attending, understanding and remembering [7]. Listening is a significant part of communication process. Communication cannot take place until and unless a message is heard and retained thoroughly and positively by the receivers/listeners. Effective listening promotes organizational relationships, encourages product delivery and innovation, as well as helps organization to deal with the diversity in employees and customers it serves. The major attributes for Listening Skills are given below in Table III.

TABLE III Attributes for Listening Skills

\begin{tabular}{|c|l|}
\hline 1 & Ability to understand the discussion \\
\hline 2 & Ability to understand the instructions \\
\hline 3 & Attentive listening \\
\hline
\end{tabular}




\begin{tabular}{|l|l|}
\hline 4 & Selective listening \\
\hline 5 & Amicable listener \\
\hline 6 & Listening with empathy \\
\hline
\end{tabular}

4. Reading Skills - Reading correctly is as important as Writing. In day to day Business, it is required to read mails, memos, letters etc. and respond to them. Poor reading skills increase the time it takes to absorb and react in workplace. Active reading is asking questions while reading using recall techniques, structure, annotation and summarizing. The major attributes for Reading Skills is given below in Table IV.

TABLE IV Attributes for Reading Skills

\begin{tabular}{|c|l|}
\hline 1 & Speed of reading \\
\hline 2 & Understanding of words \\
\hline 3 & Ability to read between the lines \\
\hline 4 & Analytical skills \\
\hline
\end{tabular}

5. Non Verbal Communication skills- It is communication of feelings, emotions, attitudes, and thoughts through body movements / gestures / eye contact, etc.Body language is the strongest signal we emit at all times, without even realizing it.[8] According to Burgoon and Saine, nonverbal communication is defined as the "Attributes or actions of humans, other than the use of words themselves, which have socially shared meaning, are intentionally sent or interpreted as intentional, are consciously sent or consciously received, and have the potential for feedback from the receiver."[9]

Nonverbal communication in an oral presentation situation can help you to engage your audience and to convey goodwill. It can also help to reinforce your message. [10]The major attributes for Nonverbal communication are given below in Table V.

TABLE V Attributes for Nonverbal communication
\begin{tabular}{|l|l|}
\hline 1 & Voice tone \\
\hline 2 & Facial expression \\
\hline 3 & Body language and gestures \\
\hline 4 & Eye contact with the audience \\
\hline
\end{tabular}

6. Technology - Advancement in communication and technology has changed the pace and face of business. Internet, email, cell phones and blackberries have made it easy to work from home. E mail communication is incontestably a crucial component of everyday business life. [11] The flow of electronic messages, sent and received on a daily basis, is a cornerstone of organizational communication. [12] Teleconferencing and Collaboration using technology solutions are a need of today as business needs to be conducted from different parts of world - across time zones, countries, regions, cities, languages etc. The major attributes for Technology are given below in Table VI.

TABLE VI Attributes for Technology

\begin{tabular}{|r|l|}
\hline 1 & Using office technology (Fax, Photocopier etc.) \\
\hline 2 & Using work related software packages like word, excel, power point etc. \\
\hline 3 & Using Email \\
\hline 4 & Using Internet/Web \\
\hline 5 & Using voice mail \\
\hline
\end{tabular}




\begin{tabular}{|r|l|}
\hline 6 & Using projectors \\
\hline 7 & Using audio visual aids for making presentations \\
\hline
\end{tabular}

7. Ethical and Cultural Diversity - Increased and improved communication in today's internet age has led to intercultural communication. An issue of race, gender, ethnicity, language and sexual orientation become hotter and hotter in national politics, so they actually affect the workplace. [13]. People talk and communicate across states, cultures, and / or religion. While technology has made communication faster and easier, it is important that intercultural communication is handled with a lot of sensitivity. The major attributes for ethical and cultural diversity are given below in Table VII.

TABLE VII Attributes for Ethical and Cultural diversity

\begin{tabular}{|c|l|}
\hline 1 & Recognizing discriminating languages \\
\hline 2 & Knowledge about International / cross cultural communication issues \\
\hline
\end{tabular}

8. Personality - Physical appearance always contributes towards how people perceive a person. Neatly combed hair, ironed clothes and a lively smile will always carry more weight than words. Confidence and a positive approach are very helpful in effective communication. Nervousness and over excitement lead to stammering and ineffective communication. One should learn to keep control on self-emotions and be very careful about what is being said and how it is said.

Personality is a set of qualities that make a person distinct from others. The word Personality originates from the Latin word "Persona "which means a mask.

It has been aptly said,

Reputation is what people think you are,

Personality is what you seem to be,

Character is what you really are. [14]

The major attributes for Personality are given below in Table VIII.

TABLE VIII Attributes for Personality

\begin{tabular}{|c|l|}
\hline 1 & Professional etiquettes and mannerism \\
\hline 2 & Dressing sense \\
\hline 3 & Table manners (dining etiquettes) \\
\hline 4 & Emotional maturity/emotional intelligence \\
\hline 5 & Being courteous \\
\hline
\end{tabular}

\section{IDENTIFICATION OF MOST IMPORTANT FACTORS}

From the above list of factors relevant for Business Communication, we wanted to identify the most important ones for the corporate world. For doing so, we made an Expert Panel. This Expert Panel consists of 30 senior corporate executives who were having more than 15 years of experience in different industry segments.

While identifying the panel members, we made sure that they belong to diversified industries (like banking, nonbanking financial services, consultancy, IT, IT enabled services, Service, Hospitality, FMCG, and Consumer Durables etc.) and have diversified work experience - ranging from 15 years to 35 years.

We requested the expert panel members to give their point of view about factors affecting Business Communication without considering their area or department or service sector, but to scrutinize it from general management perspective.

By doing so, we wanted to ensure that we identify Critical and Important Business Communication attributes for corporate - without being specific to any industry segment. 


\section{BASIS FOR SELECTION}

We spoke to each panel member personally and explained the purpose of the survey and approach adopted. We shared with them the relevant factors and attributes of Business Communication and requested them to categorize each attribute as Critical, Important, Desirable or Not relevant. We have ratified only those attributes which were categorized as Critical or important by more than $60 \%$ of panel members (i.e. 18 panel members).

Format for the panel members to classify the business communication attributes:

\begin{tabular}{|l|l|l|l|l|l|l|}
\hline \multicolumn{3}{|l|}{} & \multicolumn{4}{|l|}{ Please write 1 for the most appropriate category } \\
\hline S.No. & Skill & Attribute & Critical & Important & Desirable & Not Relevant \\
\hline
\end{tabular}

Please find the final list of selected attributes as below in Table IX.

TABLE IX - List of Final Attributes:

\begin{tabular}{|c|c|c|}
\hline S.No. & Skill & Attribute \\
\hline 1 & Written communication & Using correct English grammar \\
\hline 2 & Written communication & Using correct sentence structure \\
\hline 3 & Written communication & Completeness of communication \\
\hline 4 & Written communication & Being precise /accurate in quoting figures \\
\hline 5 & Written communication & Etiquettes for email writing \\
\hline 6 & Written communication & Having lucidity (clarity) of thought and ideas \\
\hline 7 & Written communication & Being affable and courteous while writing \\
\hline 8 & Written communication & Writing Reports \\
\hline 9 & Oral Communication & Giving individual oral presentation \\
\hline 10 & Oral Communication & Using correct pronunciation \\
\hline 11 & Oral Communication & Using effective interpersonal skills \\
\hline 12 & Oral Communication & Style of communication \\
\hline 13 & Oral Communication & Participating in meetings \\
\hline 14 & Oral Communication & Closing conversation (those lead to nowhere) politely \\
\hline 15 & Oral Communication & Clarity of thought while speaking \\
\hline 16 & Oral Communication & Using correct grammar while speaking \\
\hline 17 & Oral Communication & Analytical and organized \\
\hline 18 & Oral Communication & Telephone etiquettes \\
\hline 19 & Oral Communication & Using appropriate wordings \\
\hline 20 & Oral Communication & Using precise / crisp sentences \\
\hline 21 & Oral Communication & Negotiation skills \\
\hline 22 & Oral Communication & Resolving conflicts \\
\hline
\end{tabular}




\begin{tabular}{|l|l|l|}
\cline { 3 - 3 } 23 & Listening Skills & Ability to understand the discussion \\
\hline 24 & Listening Skills & Ability to understand the instructions \\
\hline 25 & Listening Skills & Attentive listening \\
\hline 26 & Listening Skills & Amicable listener \\
\hline 27 & Reading Skills & Ability to read between the lines \\
\hline 28 & Reading Skills & Analytical skills \\
\hline 39 & Nonverbal communication & Facial expression \\
\hline 31 & Nonverbal communication & Body language \\
\hline 32 & Technology & Eye contact with the audience \\
\hline 33 & Technology & Using work related software packages like word, excel, power \\
\hline 34 & Technology & Using Email \\
\hline 35 & Technology & Using Internet/Web \\
\hline 36 & Ethical and cultural diversity & Recognizing discriminating languages \\
\hline 37 & Ethical and cultural diversity & $\begin{array}{l}\text { Knowledge about International / cross cultural communication } \\
\text { issues }\end{array}$ \\
\hline 38 & Personality & Professional etiquettes and mannerism \\
\hline 39 & Personality & Dressing sense \\
\hline 40 & Personality & Emotional maturity /emotional intelligence \\
\hline 41 & Personality & Being courteous \\
\hline
\end{tabular}

\section{CONCLUSION}

The purpose of this survey was to identify the attributes for eight core Business Communication skills from the viewpoint of corporate world. As B-Schools are training their students for the corporate world, they can integrate these attributes while designing / developing course curriculum for Business Communication.

From the survey we have identified 41 most important Business communication attributes under eight core business communication skills. Faculty members can accentuate the Business Communication requirements of corporate, and train the students accordingly. Students also can apprehend what are the expectations / requirements of Corporate, as far as their communication skills are concerned and contrive themselves for their future endeavors.

\section{REFERENCES}

[1] Bergin F.(1981).Practical Communication,2nd Edition, Pitman books Itd,p.1

[2] (Retrieved on 10th Feb 2013) http://www.abahe.co.uk/Free-En-Resources/English-for-Managers-BusinessCorrespondance.pdf - Arab British Academy for Higher Business Communication

[3] Lesikar, Flatley, Rentz and Pande N.(2009).Business Communication: Making Connections in a Digital World (11th edition),Tata McGraw,p.1

[4] Raina R. \&Pande N. (2012). Communication Competence of Indian Engineers in IT \&ITeS Sector, The Indian Journal of Industrial Relations, A Review of Economic \& Social Development (IJIR), 47 (3) p. 511.

[5] (Retrieved on 10th Feb 2013) https://sites.google.com/site/ingjudeasongwe/management/businesscommunication

[6] (Retrieved on12th feb2013) 
http://www.managementstudyguide.com

[7] Beebe S \& Beebe S.(1991),Public Speaking ,An Audience - Cantered Approach, Prentice Hall,p.44

[8] Mitra.B(2011), Personality Development \& Soft Skills,(1 ${ }^{\text {st }}$ edition) Oxford, p.156

[9] Burgoon,J.K. \&Saine ,T.(1978).The unspoken dialogue: An introduction to nonverbal communication. Boston : Houghton Mifflin

[10] Walker R. (2006).Strategic Business Communication : An Integrated Ethical Approach, Thomson Higher Education, p.184

[11] Rice, R.E. \&Case ,D (1983)Electronic Message System in the University: A description to use and utility, Journal of Communication, Vol.33 No.1,p.131.

[12] Rice, R.E.\&Shook,D.(1990), Relationship of Job Categories \& Organizational levels to use of communication channels, including electronic mail, a meta-analysis\& extension, Journal of Management studies,vol.27, No.2,p.195

[13] Hattersley M. \&Mcjannet L.(1997),Management Communication ,Principles and Practice, McGraw Hill,p.196

[14] Mitra.B(2011), Personality Development \& Soft Skills,(1st edition) Oxford, p.11

\section{Author' biography with Photo}

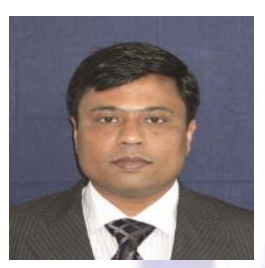

Deepak Verma is Assistant Professor in Humanities and Social Sciences department at the Jaypee Institute of Information \& Technology, Noida, India. He is doing Ph. D. in Management discipline (Research Area - Business Communication). (deepakverma711@rediffmail.com, deepak.verma@jiit.ac.in)

Dr. Neerja Pande is Associate Professor of Communication at Indian Institute of Management Lucknow, Noida Campus, India.(neerja.pande63@gmail.com) 